Зорица Томић

Универзитет у Београду

Филолошки факултет
130.2:316.7

https://doi.org/10.18485/climb.2017.5.1.ch9

\title{
КУЛТУРА У СВЕТЛУ ПОСТХУМАНИСТИЧКЕ И ТРАНСХУМАНИСТИЧКЕ ПЕРСПЕКТИВЕ
}

\section{Садржај}

У савременој теорији, термини постхуманизам и трансхуманизам, иако носе различита значења, често се интерпретирају најпре као синоними, а потом и као нека врста платформе на којој се појављују дивергентне, чак међусобно искључиве концепције о човеку. Различите теоријске орјентације које у светлу савременог научног, а пре свега био-технолошког развоја изазивају и/или опозивају класични појам хуманитета, отврају простор не само за њихову критичку евалуацију већ и нужност редефинисања категорије „културе“ у новом техно-социјалном окружењу,.

Кључне речи: Постхуманизам, трансхуманизам, култура, природа, технологија, прогрес

\section{Увод}

14. јуна 2017. је у Palais de Nations у Женеви, организована конференција о Транс-хуманизму и сајбер култури. Основна идеја скупа, била је испитивање везе између људских права и развоја науке и технологије. Према мишљењу организатора, развој у биологији, нано-технологији и комјутингу поставља бројне изазове концепту људских права и отвара питање о томе да ли будућност доноси хармонију са машинама, или пак свет у којем ће роботи контролисати људе. Ако се овоме дода и чињеница да је неколико месеци раније у фебруару исте године билионер Е.Муск изјавио да ће „људи мора- 
ти да се споје/интегришу са машинама“ , најпре прихватајући мождане импланте - не смо зато да би еволуирали већ да би могли да прате машине које су сами створили - онда је питање о трансхуманизму, постхуманизму и нужности превредновања концепта културе, једно од горућих, тим пре што је са развојем трехнологије, трансхуманизам од једног техно-утопијског и научно фантастичног пројекта постао покрет који има све више поклоника.

Чувена Протагорина изрека да је „човек мерило свих ствари“, која је представљала наратив на којем је рођена епоха хуманизма, у сазнајно-теоријском смислу претпоставља став да човек спознаје само однос који има према свету објеката, осносно, према свему ономе што чини његово Друго.

Потреба да се одреди differentia specifica људског добија своје заокружење управо у епохи хуманизма. Еклсклузивна позиција људског бића препозната је у његовој јединственој способности да креира културу (да буде њен Субјект) као комплексни ситем симболичких поредака као што су језик, митови, религија, уметност, наука, уређено друштво, сврховита пракса и морално деловање.

Заједнички именитељ свих филозофских одређења човека - од homo fabera, zoon politikona, animal symbolicuma, до бића које препознаје и креира лепоту, морално делује, жуди за истином, бића које плаче или се смеје, које се спонтано или плански игра и такмичи, па све до бића које се нада и које верује - јесте јединствена људска способниост да се односи. Већ у Марксовој тези да је „животиња безодносна“ и „стопљена са природом“, садржана је идеја о природи као референтној фигури Разлике.

Антропоцентрички дискурс западноевропске мисли у свом средишту има концепт човека као Субјекта, односно, као бића односа и културе. Категорија културе развија се превасходно на темељу не само разлике већ и оштре супротстављености према категорији природе. Упућујући на античке изворе као на основу из које је настала средњевековна концепција културе као cultura mentis, односно, каснија подела на материјалну и духовну културу, Клебер и Клакхон (Kroeber, A, Klukhohn, C, 1963:15) сматрају да се на тим темељима развија дискусија о поларности природа-култура. Читава историја западноевропеске култтуре могла би да се посматра и као својеврсно 
Култура и/или наука

продубљиваље јаза између ових категорија. „Ако се култура у најопштијем смислу разуме као њудска пракса која је сврсисходно усмерена [... ] онда се особеност културе мора разумети као способност човека да у већини случајева превазиђе природне услове и искористи их за своје циљеве [...] То осећање различитиости и супериорности почива на способности преображавања, односно култивисања [... ] природе“ (Томић, 3, 2001: 14)

Нова димензија у тумачењу и разумевању појма културе развија се напоредо са појавом термина цивилизација у 18. веку. Иако се у француској и британској теорији термини културе и цивилизације изједначавају, у немачкој је приметна супстанцијална разлика (Петровић, С 1989:8). Наиме, разлика између цивилизације и културе, практично је разлика „између сфере тахнике, материјалне културе или, шире, друштвеног бића - и сфере духовних облика, уметности, религије, морала, филозофије, језика“ (Томић, 3. 2001:19). Х.Маркузе сматра да однос између категорија цивилизације и културе може да буде артикулисан као однос између средстава (технички прогрес) и циља (сфера уживања и људске среће). У својој критици грађанске културе Маркузе указује на опасност која се налази у срцу савремености: „, Цивилизација преузима, организује и продаје културу [...] интеграција културних вредности у постојеће друштзво укида отуђење између културе од цивилизације и тиме изазива попуштање између "требати" и "бити" (који је реалан историјски затегнут однос), између потенцијалног и актуелног, будућности и садашњости, слободе и нужности" (Маркузе, Х, 1977:228-229)

Тако се показује да концепт културе као оплемењене/ продуховљене природе који своје уобличење добија у ренесанси, представља основу помаљајуће епохе хуманизма.

Шта је, дакле, донео хуманизам?

Најпре веру у моћ разума, етички концепт људског дигнитета, капацитет за самоодређење, одбацивање слепог ауторитета вере али такође и ексклузивистичку позицију човека. Она је подразумевала слику света у којем се људско биће третира као највиша и најсавршенија форма живота. У ренесенси, људска мисао се буди а човек и природа постају предмети истраживања.Управо је ренесанса изнедрила концепт зналца, човека који је овладао знањем али и који 
је морално уздигнут. Парадигма те слике света изложена је у делу Пико дела Мирандопле, Беседа о људском достојснству (1486), пре свега у тези према којој човек није једном за свагда дат, већ је биће које се развија и постаје.

Развој науке доноси критичко резоновање али истовремено и веру у аутоматизам прогреса. Модерна идеја прогреса (Г. Фон Рихт 1989), јавља се напоредо са развојем људског знања и технологије у епохи ренесансе и реформације. Али „просветитељска идеја о прогресу као о „обећаној земљи“ слободе и разума, која ће се остварити када стари иодоли буду скршени, показује своју немоћ пред концептом напретка који се операционализује кроз реификовано поистовећивање са техно-економским растом [...] напретка у чијем се окриљу растачу идеје еманципације и аутономије човека“ (Томић, 3, 2001:29).

Са друге стране, једностраност позитивизма отворила је простор за појаву ирационализма који у својим разчличитим оспољењима настоји да покаже да је разум немоћан да обухвати сферу стваралаштва и духовоности. Фантазми о научном прогресу али истовремено и страх од новума, што је одувек пратило развој науке, са подједнаком снагом били су чиниоци културних промена. Тако је у западноевропској култури, посебно у 20. столећу могућно детектовати две основне струје - тријумфалистичку и катастрофичну.

Генерално узев катастрофична орјентација упућује на опасност одзлоупотребе технологије. Тако на пример, Б. Расел у есеју Икарбудућност науке (1924) излаже тезу да ће без развијања љубазности и доброте развој науке и повећање технолошке моћи само повећати људску способност за повређивање других, док О. Хаксли у Врлом новом свету (1932) артикулише својеврсну негативно-утопијскуперспективу дехуманизације која настаје као последица развоја технологије (слика света у којем психолошко условљавање, промискуитетна сексуалност, опијати и биотехнологија представљају алатке тоталитарне контроле). Х. Маркузе (1969:113), позивајући се на Фројдову тезу о репресивном карактеру културе, упозорава на опасност од „репресивног начела прогреса“ у којем „оно чему се тежи мора непрестано да буде жртвовано разуму, а срећа трансценденталној слободи“. Једна од најпроминентнијих критичких перспектива је она коју 
Култура и/или наука

је у свом делу изложио Ф.Фукујама (2002). Упозоравајући не само на потенцијални губитак људскости који иде напоредо са новим трендом технолошког унапређења људских способности, а тиме и на проблем немогућности успостављања моралних граница, Фукујама у проблему тзв. „биополитичке трансценденције“ сагледава политичке и социјалне, а тиме и културне последице политичке економије биотехнологије.

Тријумфалистичка струја, нарочито након 2. светског рада, развија својеврсни оптимистички футуризам у чијем је средишту технолошки прогрес, и посебно компјутерска технологија. Са друге стране и наука почиње да се бави спекулативним мишњељем креирајући простор за развој научно-фантастичног литерарног жанра. Развој кибернетике и теорије информација, елабориран на Мејси конференцијама одржаним између 1943. и 1954. донео је нови и револуционарни поглед на човека, као на биће (ентитет) које процесује информације (и у том смислу се не разликује од компјутера).

Занимљиво је да исте године када је Фукујама објавио своју студију, Г.Сток (2002) објављује своју, отворено бранећи техно-прогресивистичку тезу, отварајући питање генетском инжењерингу као о неизбежној будућности у којој ће људска врста бити фундаментално промењена.

Апартно од вредносне перспективе, већ 80-тих година 20. века појављује се теоријско интересовање за постхуманизам и трансхуманизам. Иако различити, они имају заједничку орјентацију према технологији, па би могло да се каже да и постхуманизам и трансхуманизам , додуше на другачије начине, излажу снажну веру у „техногенезу“.

\section{Постхуманизам}

Постхуманиозам представља широк правац у савременој теорији у чијем је средишту питање о привилегованом месту хуманитета у антропоцентричком дискурсу, па зато не чуди што постхуманизам отвара низ етичких и еколошких питања. Префикс пост, међутим, не имплицира темпоралну димензију, већ пре представља орјентир као ономе што је у оквиру владајуће парадигме било занемарено 
или пропуштено. Према неким ауторима (Ferrando, F 2013:29), корени постхуманизма, појављују се већ са првим таласом постмодернизма, посебно у феминистичкој литаратури у којој се овај појам доводи у блиску везу са пост-антропоцентризмом. С обзиром на оотваранје проблема тела и идентитета, историја постхуманизма може бити интерпретирана и као историја расправа о вредности људске медицинске и технолошке метаморфорзе.

Постхуманизамнастојидауместоцентралногместасубјективности прихвати хетерогеност различитих начина постојања пре свега због њихове разноликости и тиме због њихове јединствености, а не због њихове мање или веће способности да се приближе нормативној слици „нас“. Постхуманизам, наиме, тврди да класични хуманизам остаје заробљен у својој сопственој догми, о онтолошкој разлици (и њеним етичким консеквенцама) између људског бића и осталог живог света.

Међутим, постхуманизам може бити схваћен и као постексклузивизам у чијем је центру опозивање било каквог дуализма (човек и свет) као и демистификовање онтолошке поларизације која отуда следи. Савремени постхуманистички дискурс можда је најјасније изложен у сада већ чувеној студији К. Хејлс (Hayles, С 1999) , Како смо постали постхумани, у којој ауторка указује на тензију између различитих верзија постхуманитета које настају напоредо са развојем интелигентних машина. Према њеном мишљењу, постхуманизам најпре привилегује информацију у односу на материјалну инстанцу, тврдећи да је њено „отеловњеље“ у биолошком супстрату пре историјска случајност него неизбежност живота. Друго, постхуманизам сматра да је свесност само епифеномен, треће да је тело само протеза којом морамо да научимо да рукујемо и коначно, да нема суштинске разлике између телесне егзистенције и компјутерске симулације (Hayles, C, 1999:10).

Отуда постхуманизам може да се разуме и као пост-центрирање, будући да препознаје не један већ мноштвио центара дискурса. Наиме, постхуманизам опозива и сам концепт централности центра, а тиме и хијерархизовану структуру света на чијем се врху налази класични (хуманистички) концепт човека. Тако се постхуманизам појављује и као нови филозофски правац у којем се отвара простор за мултидимензионално промишњаље стварности. 
Култура и/или наука

\section{Трансхуманизам}

Трансхуманизам је покрет у оквиру којег се преиспитује место хуманитета у односу према могућој биолошкој и технолошкој еволуцији. Основна идеја је усавршавање људскости уз помоћ технологије, са циљем продужета људског живота - од регенеративне медицине, до нанотехнологије и аплоудовања мозга. Трансхуманизам је веома широка платформа у чијем је центру концепт трансформације човека путем технологије. Заговорници трансхуманистичког покрета сматрају да људски интелектуални, физички и психолошки потенцијали могу и морају да буду унапређени свим сада расположивим и новим, помаљајућим технологијама. Од генетске модификације, до импланата који ће нас учинити паметнијима и дуговечнијима, до унапређења физичких капацитета - браниоци ове тезе виде будућност људскости у трансцендирању ограничења физичког тела уз помоћ технологије.

Иако је идеја о унапређењу људских потенцијала одувек била фантазам оличен не само у митским јунацима већ и у наративу о супер-човеку, модерно значење термина се везује за Џ. Хакслија који је, педестих година 20. века артикулишући појам „трансхуманизам“, најавио ново доба у којем ће људско биће трансцендирати своја биолошка ограничења. У 21. веку тај тренд се развија између осталог и кроз крионику, различите технологије продужења живота, покрет телесне модификације, трансгендеризам, биохакинг итд. Трансхуманизам се може разумети и као својеврсни културни покрет, који рачуна са поменутим технологијама као чиниоцима нове еволутивне фазе. Један од водећих заговорника технозелотизма, Реј Курцвел у својој студији (Kurzweil, R, 1999) уводи у оптицај појам сингуларности.. Према његовом мишљењу, сингуларност би могла да се схвати као нова епоха владавине вештачке интелигенције и тиме као нова култура која ће се темељити на закону убрзања прогреса у домену технологије: будуће машине ће бити људске чак иако нису биолошке.

Иако су кртичари трансхуманизма, и данас орјентисани превасхгодно на напор да разоткрију његове еугеничке потенцијале и политички проблем расподеле техно-моћи, његови браниоци разрађују концепт нове терминологије - да споменемо само неке, као што су ре- 
прогенетика (reprogenetics) или герминални избор (germinal choice што је заправо селективна генетичка модификација) - са циљем да сам покрет аболирају од било какве негативне конотације.

Теза да је перманентни прогресу функцији самотрансформације, упућује на својеврсни оптимизам који је у центру, у основи веома дивергентног трансхуманистичког покрета (либертарианизам, демократски трансхуманизам, ексторпианизам итд.) Трансхуманистичка фасцинација науком и технологијом, у форми својеврсног ултра-хуманизма, налази се у опасности од склизавања у техно-редукционизам. Техно-редукционизам у овом смислу упућује на смештање Технолошког на место Хуманитета, чиме се заправо реновира концепт хијерархијског поретка против којег је постхуманизам, као идејни концепт трансхуманизма, најпре устао.

У основи можемо да се сложимо са А. Пилшом (Pilsch, A, 2017) који у својој студији износи тезу да је историја западноевропске мисли обележена, између осталог, значајном традицијом „еволуционог футуризма“. Еволуциони футуризам је данас, према Пилшовом мишљењу, препознатљив у трима сферама: кибернетици, биологији и спиритуализму (духовне технологије саморазвоја). У основи, ради се о креирању новог мита - мита о савршеном човеку. Креирање новог мита припада домену ремитологизације, а тиме и домену културе. Са друге стране, трансхуманизам, а посебно идеја о епохи сингуларности, не само да у свом средишту има калсични појам прогреса који се третира као експоненцијални, већ се суштински ослања на дарвинијански концепт у тумачењу културе.

\section{Место културе у постхуманистичкој и трансхуманистичкој перспективи}

Иако се читав корпус друштвених наука темељи на категорији културе, као људског дела-преобликовања и култивисања природе ( а тиме свакако и људске природе) - питање о односу културе и природе (nurture/ nature), данас, посебно у светлу поменутих технолошких промена и нове теоријске парадигме, добија на значају и отвара бројна питања.

1. Најпре, једна од најпроминентнијих одлика савременог света је ишчезавање границе између природног и артифицијелног (култур- 
ног), због све снажнијег утицаја човека на преобликовање природе уз помоћ модерне технологије. Категорија „природе“ која се перципирала као подлога на којој циљано интервенише људско биће, губи своје класично значење, тим пре што се у савременој литератури све чешће користи термин „окружење“ (Robertson, G et all (1989), Sagoff, M 2005). Другим речима, с правом можемо да питамо да ли се данас уопште може говорити о „природности“ природе?

2. Штавише, класична линија разграничења између nature и culture, која се формирала на темељу перципирања природе као моћне, непобедиве, застрашујуће и „дивље“ (Томић, 3, 2001) као да више не одговара односу међу овим сферама. Наиме, управо се у покрету „зелених“ и свих осталих покрета за очување природе, односно, за рационално и одговорно коришћење технологије, примећује разумевање културе (као техно-универзума) као разарајућег, односно „дивљег“ агента прогреса, док се природа третира као егзотични топос који треба сачувати, и оставити изван домашаја људске интервенције.

3. И постхуманизам и трансхуманизам се у основи надовезују на основне идеје хуманизма, као што су усавршавање, рационалност, аутономија мишљења, перфекционизам. Све ове категорије повезује концепт „култивације“ који се појављује као средишње место западноевропског поимања културе као „оплемењивања, усавршавања, преобликовања и превазилажења“ природе. Следствено томе, са правом се може поставити питање о есхатолошкој димензији тезе о прогресу. Како ће, наиме, да изгледа свет, када једном, природа у потпуности буде савладана и стављена под контролу суперинтелигенције?

4. Може ли уопште да се говори о култури у свету у којем ће и категорија природе изгубити своје значење, будући да ће већ увелико бити артифицијелно трансформисана и саображена ултраинтелигенцији постхуманитета?

5. Ако је трансхуманизам својеврсни „културни пројект“, где је позициониран субјект који ће перципирати његову реализацију? Ако ттрансхуманизам претпостаља дефинитивну сепарацију информације и материјалности, како и на који начин ће бити креиран мета-наратив?

6. Крајносни феномен који се најављује у оквиру постхуманистичког наратива и трансхуманистичке утопије садржи својеврсни па- 
радокс: императив „постати оно што стварно јесмо“, односно, развити своје потенцијале, могућно је само тако што ћемо на крају бити конструисани од стране нечег другог, нећег што стварно нисмо ми.

7. Концепт будућих бића чији ће капацитети далеко превазилиазити оно што се данас сматра људским, појављује се као нека врста културног иделала. Ако техноутопија, међутим, претпоставља свет без „људи“, ако је, наиме, будућност обећана земља артифицијелне интелигенције, аплоудованих мозгова и неуралних интерфејсова (постхуманитет), како се уопште може говорити о култури? Ако је култура људско дело, може ли се говорити о култури у свету без људи?

8. Да ли крај антропоцентризма претпоставља тренутак у којем ће креирање супер-интелекта бити последњи људски проналазак? Да ли то значи да ће од часа када компјутер а не човек буде креирао свет, човек постати излишан? Да ли већ сада можемо да се сматрамо диносаурусима, спремним да заувек нестану са лица земље? О каквом хуманизму, дакле, уопште може да се говори у фази његове пост и транс будућности?

9. Које су политичке и социјалне последице најављене будућности? Да ли транс и пост концепти у тежњи за постизањем савршенства (и уосталом како је савршенство оно конципирано?) прикривају у основи тоталиратни пројекат креирања супер-друштва (рационално-планирано-тоталитарно)? Може ли се оно (као уосталом и било које друго друштво) мислити изван питања о његовим етичким стандардима?

10. Није ли са постхуманизмом и трансхуманизмом у дискурс уведена нова техно-утопија, у којој наука обезбеђује остварење рајског стања света створеног за артифицијелну, дизајнирану, интелигентну креацију, за коју људска питања (да ли ће уопште бити Субјекта способног да пита?) живота и смрти више неће имати никаквог значаја?

11. Коначно, ако је будућност већ почела, ако је она већ на путу своје коначне култивације, може ли се уопште говорити о култури? Да ли савремена теорија уопште има капациет да се бави превредновањем свог терминолошког инструментаријума, посебно у оном свом сегменту на којем почива концепт културе као људске саморефлексије? 
Култура и/или наука

\section{Библиографија}

Ferrando, F (2013) Posthumanism, Transhumanism, Antihumanism, Metahumanism, and New Materialisms- differences and relations, Existenz, an International Journal in Philosophy, Religion, Politics, and the Arts, v.8, No2 )

Fukuyama, F (2002) Our Posthuman Future, Consequences of the Biotechnology Revolution, London, Profile Books)

Hayles, K,(1999) How We Became Posthuman, Chicago/London, University of Chicago Press

Kurzweil, R, 1999, The Age of Spiritual Machines: when Computers Exceed Human ntelligence, Viking/Penguin Books)

Маркузе, X (1969) Идеја прогреса у светлости психоанализе, Београд, Трећи програм

Маркузе, X (1977), Кулрура и друштво, Београд, БИГЗ

Петровић, С (1989) Етика и социологија, Београд, Научна књига

Pilsch, A (2017) Transhumanism - Evolutionary Futurism and the Human Technologies of Utopia, University of Minnesota press

Robertson, g, Mash,M, Tickner,L, Bird, J, Curtis, B and Putnam, T (1996), Future Natural: Nature, sciencem culture, London, Routledge)

Sagoff, M (2005) Nature and / Human nature, in is human nature obsolete?, ed. H.baillie\& T.Casey, The MIT Press

Stock, G,2002, Redesigning humans, London, profile Books)

Томић, 3 (2001), Мушки свет, Београд, Zepter Book World

Фон Рихт, Г (1989), Muт о прогресу, Београд, Трећи програм

\section{Zorica Tomić}

University of Belgrade

Faculty of Philology

\section{CULTURE IN THE LIGHT OF POSTHUMANIST AND TRANSHUMANIST PERSPECTIVE}

\section{Summary}

In contemporary theory, the terms posthumanism and transhumanism, even thou relating to the same issue are grasped as a sort of a theoretical platform, which enables various and sometime mutually exclusive concepts of humanity. Different theoretical orientations which especially under the light of bio/technological development 
challenge and/or oppose the classic notion of humanity open up the space for their critical evaluation. Hence, they imply the necessity to redefine the category of culture in the new emerging techno/social environment. 